\title{
HEMOCYTE TYPES AND TOTAL AND DIFFERENTIAL COUNTS IN UNPARASITIZED AND PARASITIZED Anastrepha obliqua (DIPTERA, TEPHRITIDAE) LARVAE
}

\author{
SILVA, J. E. B., ${ }^{1}$ BOLELI, I. C. ${ }^{2}$ and SIMÕES, Z. L. P. ${ }^{1}$
}

\author{
'Departamento de Biologia, Faculdade de Filosofia, Ciências e Letras de Ribeirão Preto, Universidade de São Paulo \\ (USP), Av. Bandeirantes, 3900, CEP 14040-901, Ribeirão Preto, São Paulo, Brazil \\ ${ }^{2}$ Departamento de Morfologia e Fisiologia Animal, Faculdade de Ciências Agrárias e Veterinárias, \\ Universidade Estadual Paulista (UNESP), Via de Acesso Paulo D. Castellani, km 5, \\ CEP 72800-000, Jaboticabal, São Paulo, Brazil \\ Correspondence to: José Esequiel B. Silva, Departamento de Biologia, Faculdade de Filosofia, Ciências e Letras de \\ Ribeirão Preto, Universidade de São Paulo (USP), Av. Bandeirantes, 3900, CEP 14040-901, Ribeirão Preto, \\ São Paulo, Brazil, e-mail: esequiel@rge.fmrp.usp.br \\ Received August 31, 2001 - Accepted November 12, 2001 - Distributed November 30, 2002
}

(With 25 figures)

\begin{abstract}
The hemocyte types, in addition to total and differential hemocyte counts were studied in parasitized and unparasitized Anastrepha obliqua larvae at the beginning and at the end of the third instar. In both developmental phases, in parasitized and unparasitized larvae, prohemocytes, plasmatocytes, granulocytes, adipohemocytes, spherulocytes and oenocytoids cells were observed. Mitotic figures indicate prohemocytes as stem cells. Prohemocytes, plasmatocytes and granulocytes are the most numerous cells in the hemolymph of A. obliqua. Difference in the total number of hemocytes was observed between unparasitized and parasitized larvae at the end of the third instar, but not at the beginning.
\end{abstract}

Key words: hemocytes, Anastrepha obliqua, fruit fly, parasitism.

\section{RESUMO}

Tipos de hemócitos e contagem total e diferencial em larvas parasitadas e não parasitadas de Anastrepha obliqua (Diptera, Tephritidae)

Os tipos de hemócitos e as contagens total e diferencial foram estudados em larvas parasitadas e não parasitadas de Anastrepha obliqua pertencentes ao início e ao final da terceira fase. Em ambas as fases do desenvolvimento, tanto em larvas parasitadas quanto nas não parasitadas, foram observados pró-hemócitos, plasmatócitos, granulócitos, adipo-hemócitos, esferulócitos e oenocitóides. A presença de divisões mitóticas indica os pró-hemócitos como células-tronco. Pró-hemócitos, plasmatócitos e granulócitos são as células mais numerosas na hemolinfa de A. obliqua. Foi observada diferença no número total de hemócitos entre larvas parasitadas e não parasitadas apenas no final da terceira fase.

Palavras-chave: hemócitos, Anastrepha obliqua, mosca-da-fruta, parasitismo. 


\section{INTRODUCTION}

Anastrepha obliqua, a member of the Tephritidae family (Insecta, Diptera), is a pest of tropical fruits, since its larvae, feeds on the fruit pulp (Bressan, 1987), turning them non viable for consumption, causing considerable economic losses. This fruit fly species is parasitized by some parasitoid wasps (Malavasi et al., 1980; Wharton, 1989; Canal et al., 1996). This could be used in their biological control. The exit of the control method, however, is directly linked to the successful development of endoparasitoids into the larval bodies, which depends on the ability to avoid encapsulation by the host immune system.

The cellular component of the capsules surrounding the parasitoids is formed by hemocytes (Ratcliffe, 1993), whose concentration in the hemolymph changes in parasitized larvae (Nappi \& Carton, 1986; Eslin \& Prévost, 1998). The population of circulating hemocytes may indicate whether the host defense system was activated or not (Brehélin, 1982), and whether any depression in the number of hemocytes contributes to the protection of the parasite (Rizki \& Rizki, 1980, 1992).

As the hemocytes are the cells involved in defense reactions in insects, they are very useful to understand the host-parasite interactions.

Since, the characterization of the hemocytes of A. obliqua is rarely encountered in the literature, we describe here the hemocyte types, as well as the total and differential hemocyte counts in the hemolymph of parasitized and unparasitized larvae of this fruit fly.

\section{MATERIAL AND METHODS}

\section{Insects}

Anastrepha obliqua larvae were obtained from infested fruits of Spondias lutea (cajá-mirim) collected in the gardens of the Universidade de São Paulo, in Ribeirão Preto, SP, Brazil. Only third instar larvae were used because they are larger and more abundant in the fruits collected than the first instars. Due to the long duration of the third instar (about 14 days), these larvae were divided as belonging to the beginning and the end of the third instar. They were identified according to Teles da Silva (1978).

\section{Hemocytes characterization}

For light microscopy (LM), the larvae were washed in distilled water and placed on ice for immobilization. Hemolymph was obtained by cutting laterally the anterior region of the larvae with a micro scissors. Hemolymph was bled directly on a glass slide and allowed to dry in natural air conditions for 20-30 minutes. During this time the hemocytes adhered to the glass. Cells were then fixed in methanol for $5 \mathrm{~min}$. After natural air-drying of the fixative, hemocytes were stained with Giemsa-Rosenfeld for 3-4 minutes and slides were rapidly washed with bidistilled water. After air drying the slides were dehydrated and mounted in Entellan.

For Scanning Electron Microscopy (SEM), hemolymph was bled directly on termanox discs after cutting the cuticle. The hemolymph slides were allowed to dry for 20-30 minutes. Then, they were fixed in $70 \%$ ethanol for 10 minutes and placed in a chamber to dry for a week. Small pieces of termanox containing hemocytes were mounted on stubs, coated with gold and examined in a JSM 5200 SEM.

\section{Hematology}

Hemolymph was obtained from the $A$. obliqua third instar larvae by cutting their anterior region with a micro scissors. After bleeding, the larvae were dissected to verify the presence of parasitoids (eggs or larvae).

Hemocyte counts were performed on individual larvae. Total hemocyte counts (THCs) were done by applying diluted hemolymph ( $1 \mu$ l hemolymph added to $5 \mu \mathrm{l} 0.1 \mathrm{M}$ phosphate buffer, $\mathrm{pH}$ 7.2) to a Neubauer hemocytometer. THCs were expressed as number of cells per $\mu \mathrm{l}$ of hemolymph. Differential hemocyte counts (DHC) were realized on hemolymph slides stained with GiemsaRosenfeld. One hundred fifty cells identified from four randomly selected fields were counted per larvae. DHCs were expressed as the mean of each hemocytes type in the total cells counted.

Differences in the THC and DHC results were tested with Student's t-test ( $\mathrm{p} \leq 0.05)$, using Sigma stat. 2.0 software. 


\section{RESULTS}

\section{Hemocyte types}

Six well-defined hemocyte types were distinguished in the hemolymph of parasitized and unparasitized $A$. obliqua larvae at the beginning and the end of the 3rd instar: prohemocytes, plasmatocytes, granulocytes, adipohemocytes, oenocytoids and spherulocytes.

\section{Prohemocytes $(P R)$}

These cells are the smallest hemocytes encountered in the hemolymph. They can be spherical (7.5-13.12 $\mu \mathrm{m}$ in diameter) or oval in shape $(5.62 \times 7.5 \mu \mathrm{m}$ to $13.12 \times 22.5 \mu \mathrm{m})$. The large and centrally located nucleus (5.6-11.25 $\mu \mathrm{m}$ in diameter) nearly fills the cell so that the cytoplasm occupies a narrow area around the nucleus, which shows a spherical shape (Figs. 13 ). The surface of the cell, under the microscope, seems to be slightly irregular. They were the unique hemocyte type presenting features suggestive of mitotic figures (Figs. 7-8).

\section{Plasmatocytes (PL)}

The plasmatocytes are highly polymorphic cells; they show rounded, oval, spindle-shaped or sometimes irregular form, viewed under LM (Figs. 4-6) and SEM (Figs. 9-11). Plasmatocytes are also variable in size. When spherical in shape, they present $13-26 \mu \mathrm{m}$ in diameter. When oval, they are $26-34 \mu \mathrm{m}$ long and $15-30 \mu \mathrm{m}$ wide. The nuclei can be spherical $(9-15 \mu \mathrm{m}$ in diameter) or oval (79.5 $\mu \mathrm{m}$ long and 9.5-1.5 $\mu \mathrm{m}$ wide).
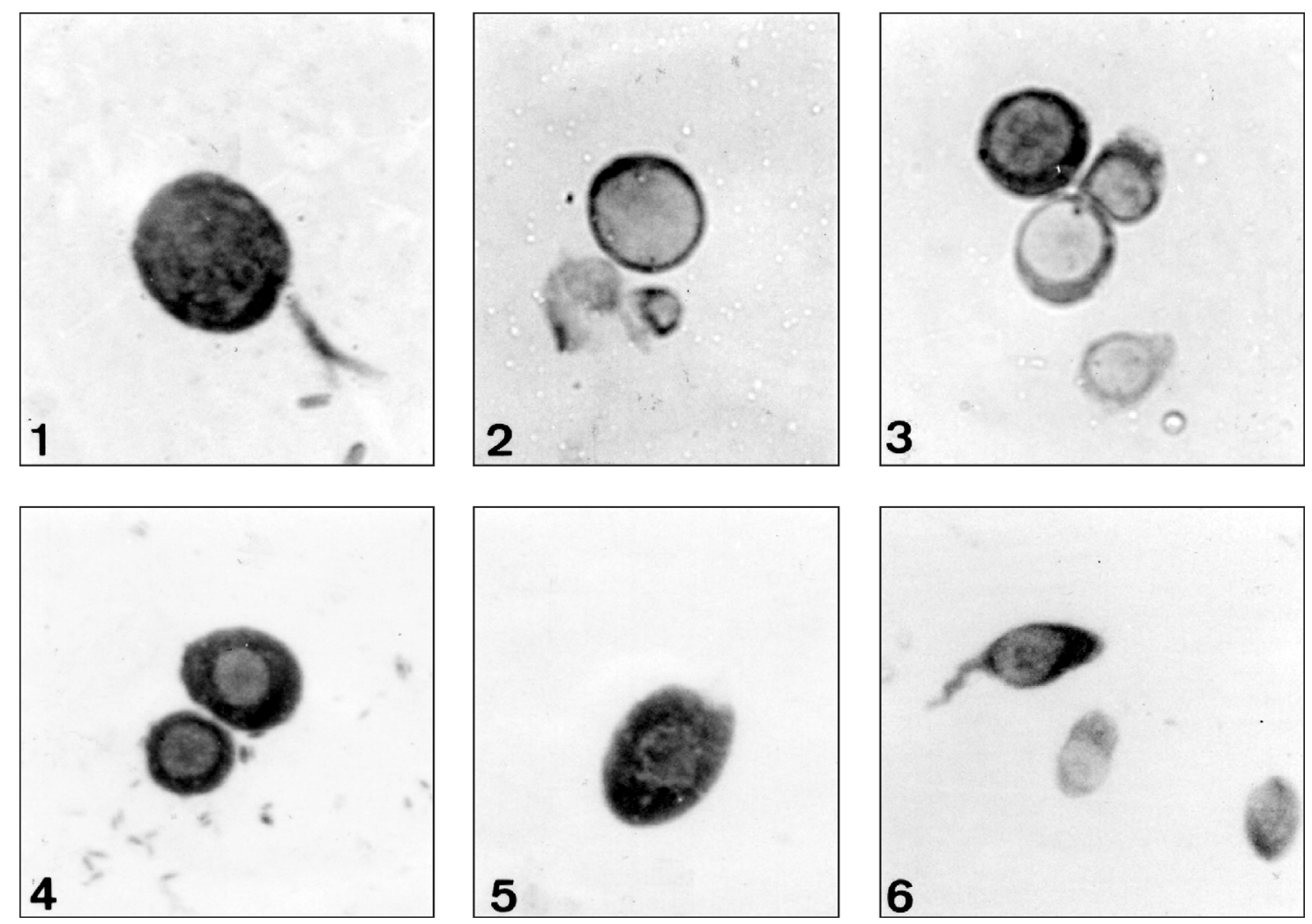

Figs. 1-6 - Hemocytes of A. obliqua larvae, after Giemsa-Rosenfeld staining: prohemocytes (Figs. 1-3: X640) and plasmatocytes (Figs. 4-6: X330). 

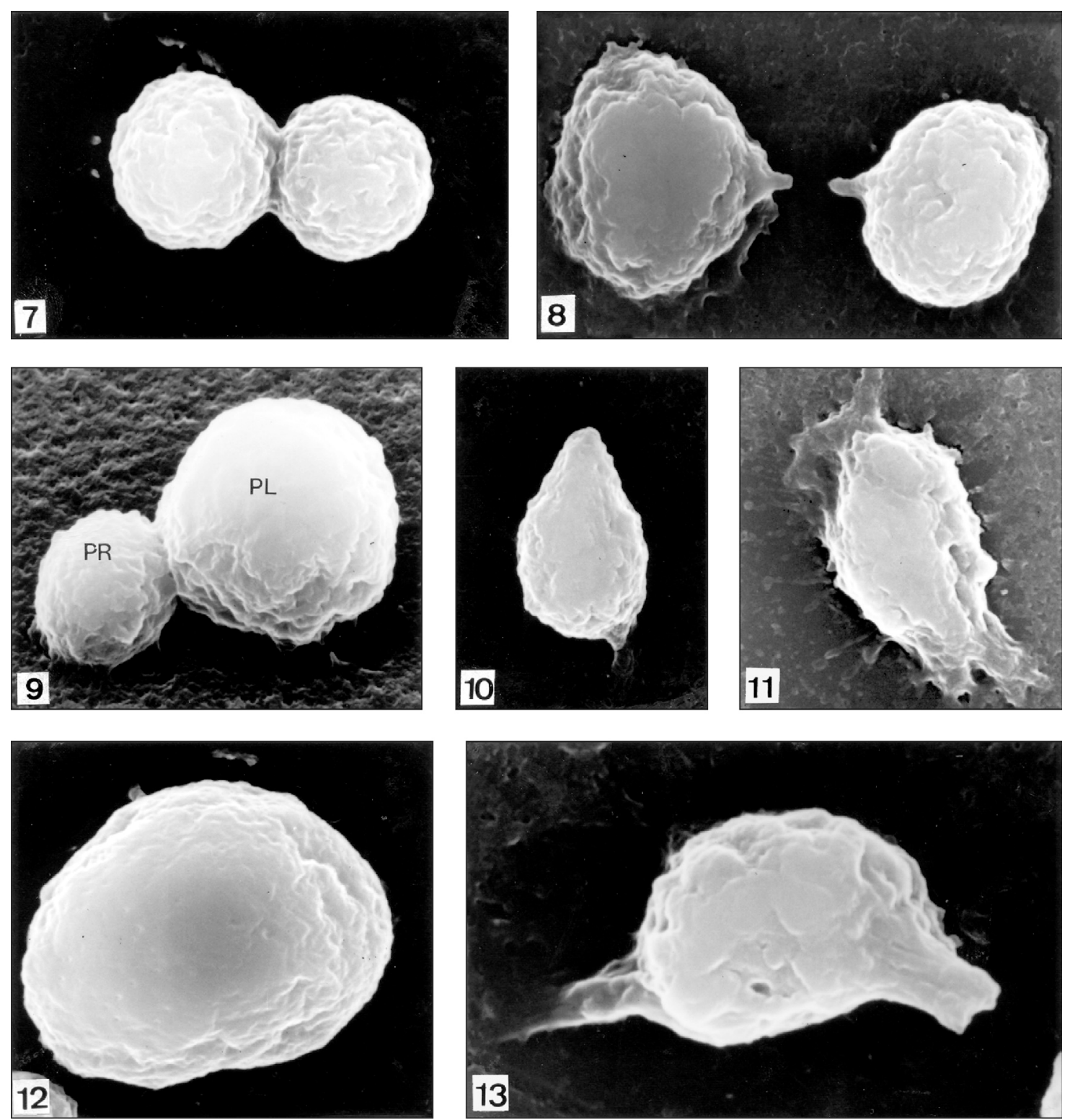

Figs. 7-13 - Hemocytes of A. obliqua by SEM: prohemocytes in mitotic cytokenesis (Figs. 7-18: X5000), plasmatocytes (Figs. 9-11, 9: X7500 and 10-11: X5000), granulocyte (Fig. 12: X5000) and adipohemocyte (Fig. 13: X7500).

The majority of the PLs are mononucleated, but some binucleated cells were occasionally observed. The irregular shape of the cells is due to cytoplasmic extensions. After the Giemsa staining, PLs show a variable number of granu- les, which can be negative or positively stained. Normally the negative granules are smaller than the positive. PLs and PRs presenting same size and shape can be distinguished one from another by the higher nuclear/cytoplasmic ratio in the latter. 


\section{Granulocytes (GR)}

After Giemsa staining, the GRs are recognized by their numerously small and highly basophilic granules, which are present in the clairblush cytoplasm. These hemocytes are variable in shape and size. They can be large or small hemocytes and have a spherical (15-22.25 $\mu \mathrm{m}$ in cellular diameter) or oval shape (13-18 $\mu \mathrm{m}$ long and 15-34 $\mu \mathrm{m}$ wide). Spherical and oval GRs present rounded nuclei with 5.6-11.3 $\mu \mathrm{m}$ in diameter. The nucleus also basophilic generally occupies a central position (Figs. 12, 14-16). The phagocytic activity of the GRs was observed in relation to the yeast present in the hemolymph of the flies (data not shown). Cells with intermediate features between PLs and GRs were also observed.

\section{Oenocytoids (OE)}

These cells can be spherical (22-35.5 $\mu \mathrm{m}$ in diameter) or oval (18.7-26 $\mu \mathrm{m}$ long and 26.5-35.6 $\mu \mathrm{m}$ wide) in shape, and present nuclei with the same general shape of the cell. Spherical nuclei are 7.5-11.3 $\mu \mathrm{m}$.

After Giemsa staining the OEs exhibit a moderate acidophilia, and reveal a homogeneous cytoplasm containing fine and weak acidophilic granulation (Fig. 17). Cells with intermediate characteristics between GRs and OEs were frequent in the slides observed.

\section{Adipohemocytes (AD)}

These cells are polymorphic (Figs. 18-21). They can be large or small in size, and have an oval or irregular shape. After Giemsa staining, the cytoplasm shows a high basophilia and a variable number of large refringent lipid-like inclusions, which sometimes obscure the nuclei contour, and appear prominent on cell surface (Figs. 13, 20-21).

\section{Spherulocytes (SP)}

The spherulocytes are variable in shape; they can present a regular or irregular shape. The cytoplasm is characterized by the presence of highly basophilic or acidophilic spherules and small spherical vacuoles (Figs. 22-23). Cells presenting intermediate characteristics between plasmatocytes and spherulocytes were encountered in the hemolymph (not showed).

The Figs. 24 and 25 show hemocytes encountered in the hemolymph of A. obliqua whose type was not identified.

Total (THC) and Differential (DHC) Hemocyte Counts

The mean of the total hemocyte counts of parasitized larvae was not significantly different from unparasitized larvae at the beginning of the 3rd instar, but was significantly higher at the end of the instar (Table 1).

By means of the DHC it was verified that at the beginning of the 3rd instar $97 \%$ and $94.9 \%$ of the total circulating hemocytes were comprised of prohemocytes and plasmatocytes in both parasitized and unparasitized larvae, respectively (Table 2). The number of prohemocytes was not statistically different in parasitized $(36.11 \pm 6.82)$ and unparasitized $(38.0 \pm 12.55)$ larvae $(\mathrm{t}=0.33$; g.f. $=13 ; p=0.05)$. Similar results were also obtained for plasmatocytes and granulocytes (Table 2 ). The granulocytes are among the most frequent hemocyte type in the hemolymph, but their relative proportion remained lower than $4 \%$ (Table 2). The remaining hemocyte types are present in the circulation, but their proportion was never greater than $1.0 \%$ (Table 2).

Despite the general similarities in the average number and percentage of hemocytes in the two analyzed phases of the third larval instar, some distinct alterations were noted. At the end of the instar, the proportion of prohemocytes and plasmatocytes in parasitized and unparasitized larvae diminishes to $87.8 \%$ and $80.5 \%$ respectively. In addition, granulocyte proportion increased from $11 \%$ in parasitized larvae to $18.1 \%$ in unparasitized (Table 2). The proportion of the other cell types remained unaltered, not comprising more than $1 \%$. As showed in Table 2, in this phase the number of prohemocytes was significantly greater in parasitized larvae $(67.8 \pm 17.14)$ than in unparasitized $(49.5 \pm 12.12)$, but no statistically significant difference was encountered between these larvae in relation to the mean number of plasmatocytes and granulocytes. 

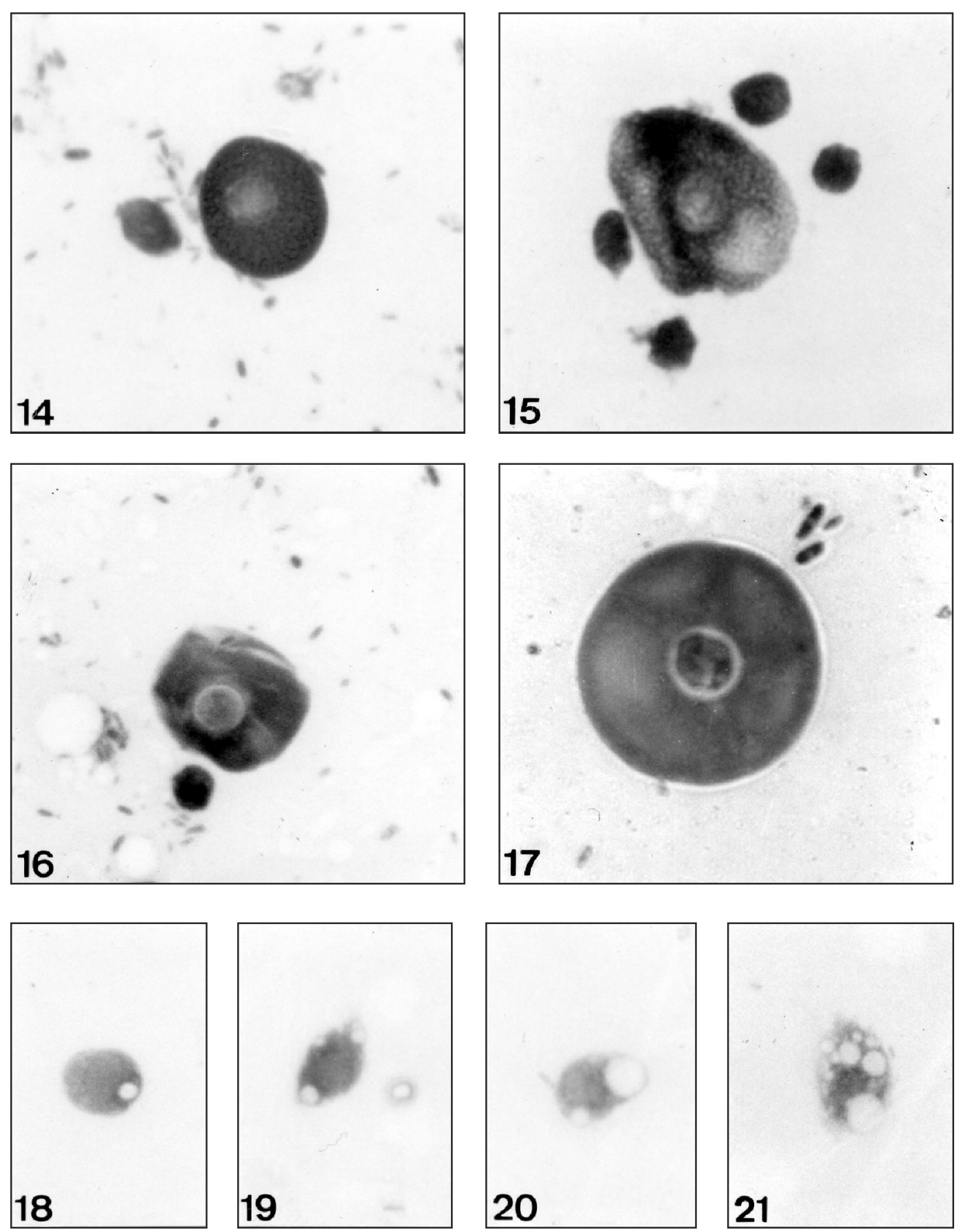

Figs. 14-21 - Hemocytes of A. obliqua larvae, after Giemsa-Rosenfeld staining: granulocytes (Figs. 14-16, 14: X270 and 15-16: X410), oenocytes (Fig. 17: X410), and adipohemocytes (Figs. 18-21: X280). 
TABLE 1

Total hemocytes counts in the hemolymph of parasitized and unparasitized $A$. obliqua larvae, at the beginning and at the end of the 3rd instar. Results (mean \pm SD) are given in hemocytes counter/ $\mu$ l.

\begin{tabular}{|l|c|c|}
\hline \multirow{2}{*}{\multicolumn{1}{|c|}{ Larvae }} & \multicolumn{2}{c|}{ Phases of the third instar } \\
\cline { 2 - 3 } & Beginning & End \\
\hline Unparasitized & $147.0 \pm 10.6$ & $210.0 \pm 144.5$ \\
\hline Parasitized & $345.0 \pm 51.1 *$ & $505.4 \pm 48.0 *$ \\
\hline
\end{tabular}

Means in the same column followed by asterisks differ significantly (t-test: -2.71 ; d.f.: $12 ; \mathrm{p}=0.019$ ).

TABLE 2

Differential hemocytes counts (means \pm s.d.) and percentage in the hemolymph of unparasitized and parasitized $A$. obliqua larvae, at the beginning and at the end of the 3rd instar.

\begin{tabular}{|c|c|c|c|c|c|}
\hline \multirow{2}{*}{$\begin{array}{l}\text { Phase of the } \\
\text { third instar }\end{array}$} & \multirow{2}{*}{$\begin{array}{c}\text { Hemocytes } \\
\text { types }\end{array}$} & \multicolumn{2}{|c|}{ Unparasitized } & \multicolumn{2}{|c|}{ Parasitized } \\
\hline & & Mean \pm sd & $\%$ & Mean \pm sd $\%$ & $\%$ \\
\hline \multirow{6}{*}{ Beginning } & PR & $38.0 \pm 12.5$ & 37.5 & $36.11 \pm 6.8$ & 35.2 \\
\hline & PL & $58.5 \pm 6.8$ & 57.6 & $63.33 \pm 4.0$ & 61.8 \\
\hline & GR & $3.83 \pm 3.8$ & 4.0 & $2.84 \pm 2.0$ & 62.4 \\
\hline & $\mathrm{OE}$ & - & 0.3 & - & 0.1 \\
\hline & SP & - & 0.3 & - & 0.1 \\
\hline & $\mathrm{AD}$ & - & 0.3 & - & 0.4 \\
\hline \multirow{6}{*}{ End } & PR & $49.5 \pm 12.1 *$ & 38.0 & $67.8 \pm 17.1 *$ & 50.4 \\
\hline & PL & $55.5 \pm 6.87$ & 42.5 & $51.2 \pm 15.5$ & 37.3 \\
\hline & GR & $23.7 \pm 13.8$ & 18.1 & $15.1 \pm 13.4$ & 11.0 \\
\hline & $\mathrm{OE}$ & - & 1.1 & - & 0.7 \\
\hline & SP & - & 0.1 & - & 0.1 \\
\hline & $\mathrm{AD}$ & - & 0.2 & - & 0.5 \\
\hline
\end{tabular}

Means in the same line followed by asterisks are significantly different (t-test: $-2.90 ;$ g.f.: $18 ; \mathrm{p} \leq 0.05)$. AD: adipohemocytes, Gr: granulocytes, OE: oenocytoids, PL: plasmatocytes, PR: prohemocytes, SP: spherulocytes.

\section{DISCUSSION}

A. obliqua 3 rd instar larvae present six hemocytes types in the hemolymph, all easily distinguishable in smears, after Giemsa staining, namely: prohemocytes, plasmatocytes, granulocytes, adipohemocytes, spherulocytes and oenocytoids. Under SEM, however, we were able to recognize only the first three types.
Gupta (1985) describes seven basic types of hemocytes, common among the different Orders of insects: the six cellular types identified in the present study plus the coagulocytes. According to Arnold (1974), coagulocytes are very fragile cells that can be observed "in vitro", only. So being, it is not impossible that A. obliqua has this hemocyte type and that the utilized methodology has not been able to discriminate it. 

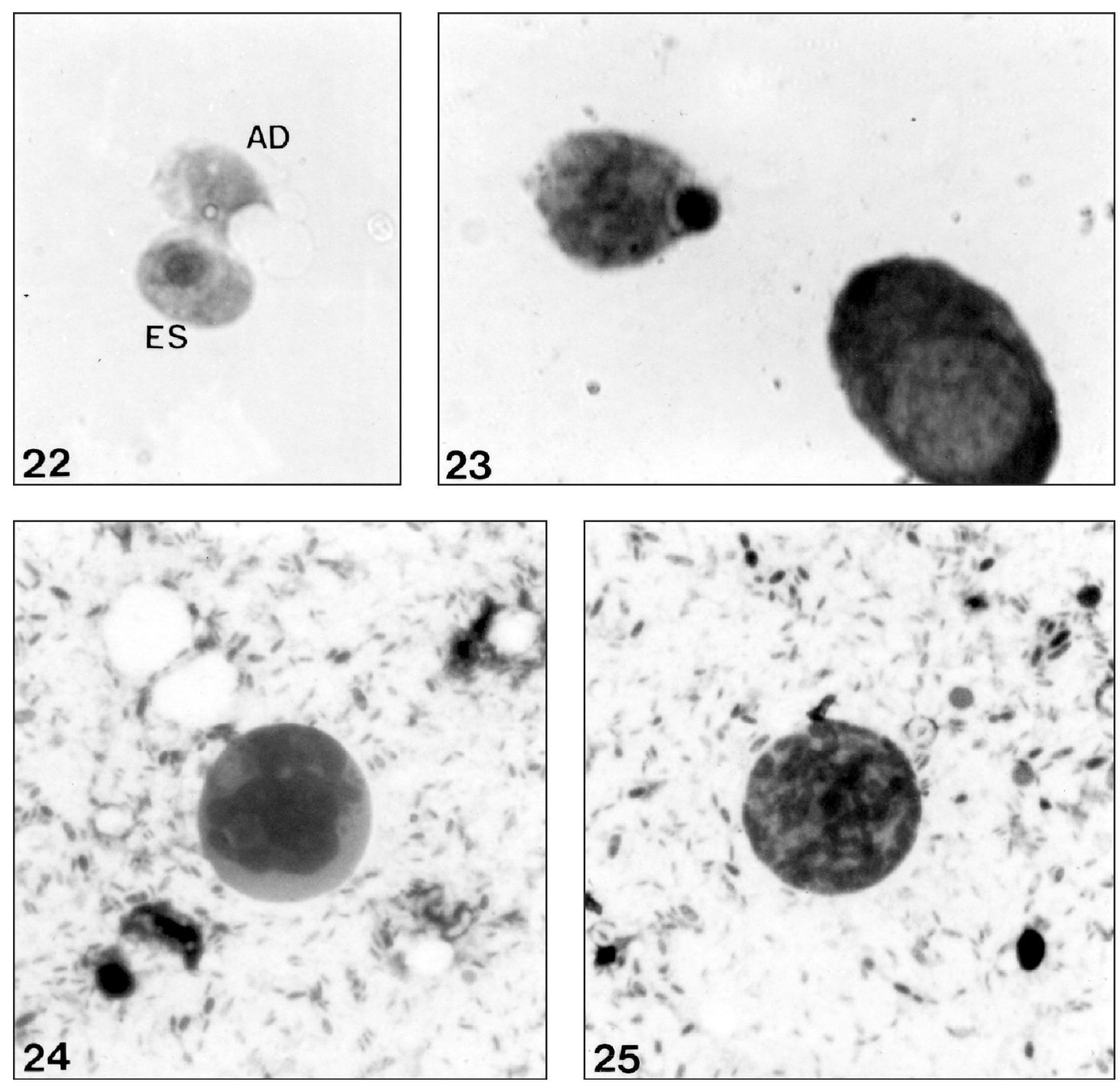

Figs. 22-25 - Hemocytes of A. obliqua larvae, after Giemsa-Rosenfeld staining: spherulocytes (Figs. 22-23: X210) and not identified hemocytes (Figs. 24-25: X340).

In spite of the difficulty to compare the hemocytes among different species, the morphology described here for A. obliqua and the data already published make this comparison possible.

Prohemocytes are unmistakable because of their small size and large nucleus-cytoplasm ratio. Consequently, prohemocytes of A. obliqua certainly correspond to the prohemocytes described by several authors for another insects (Gupta, 1979; Mall \& Gupta, 1980; Barraco \& Cestari, 1984; Gianotti \& Caetano, 1985; Chiang et al., 1988; Fenoglio et al.,
1993; Russo et al., 1994; among others). Plasmatocytes are the most variable cell in shape observed in the hemolymph smears of A. obliqua. They can be rounded, fusiform or completely irregular in shape due to cytoplasm expansions. Plasmatocytes emitting filamentous expansions have been described in many dipterans (Whitten, 1964; Barraco \& Cestari, 1984). In A. obliqua, only plasmatocytes present cytoplasm expansions. In the literature, the elongated cells or fusiform cells are identified as vermiform cells (Devauchelle, 1971; Gianotti \& Caetano, 1985). 
Granulocytes of A. obliqua appear to correspond to the granular hemocyte, cited by Gillespie et al. (1997) and reported by other investigators (Arnold \& Hinks, 1976; Barraco \& Cestari, 1984; Gianotti \& Caetano, 1991). They are easily identified by their large size and cytoplasm characteristically filled with basophilic granules in Giemsa or methylene blue-stained smears. In $A$. obliqua larvae, emission of pseudopods was not observed in the granulocytes. This data agrees with the observation of the granulocytes in some insect species (Arnold, 1974; Chiang et al., 1988), but is in disagreement with the characterization given by Olson \& Carlson (1974) and Barraco \& Cestari (1984), who described these cells as having cytoplasmic extensions.

Adipohemocytes in A. obliqua are hemocytes exhibiting a large lipid like vesicle, sometimes large enough to deform the cell. Their characteristics are similar to those observed in other insect species (see Chiang et al., 1988; Russo et al., 1994). Adipohemocytes have been regarded as granulocytes variants by some authors (Price \& Ratcliffe, 1974; Kaaya et al., 1986). Oenocytoids can be as large as the granulocytes or larger. In A. obliqua, they can be distinguished from the former by their fine granulation and, as occurrs in other insects (Barraco \& Cestari, 1984), by their acidophilic cytoplasm observed after Giemsa stainning. This type of hemocyte is not encountered in all insect species (Russo et al., 1994). Spherulocytes are easily distinguished from the other hemocytes by the presence of small basophilic or acidophilic spherules distributed in the cytoplasm. However, in the present study, spherulocytes do not show size as large as described by other authors (see Fenoglio et al., 1993; Gianotti \& Caetano, 1985). Furthermore, those types do not occur in all insects (Russo et al., 1994).

The theories about post-embryonic origin of hemocytes in insects are based on the cellular types encountered in the hemolymph. From the morphological observations presented in this study, a scheme has been devised outlining the possible relationships among the six types of hemocytes in A. obliqua. The prohemocyte is the most abundant hemocyte in the hemolymph and also the only one seen in cytokenesis. These facts have suggested a role of stem cells to them and agree with the theories of Gupta (1985) and Arnold (1979) related to the origins of hemocytes.

The intermediate forms between prohemocytes and plasmatocytes suggest the growth and differentiation of the later from prohemocytes. In a similar way, the origin of granulocytes, adipohemocytes and spherulocytes from plasmatocytes, in A. obliqua, is indicated by the presence of numerous cells presenting intermediate forms, and characteristic staining properties. Plasmatocytes, as pluripotent cells capable of producing granulocytes and spherulocytes, have also been suggested in silkworms because of the presence of intermediate forms of hemocytes observed in the hemolymph (Beaulaton, 1979). This potentiality of the plasmatocytes is in agreement with the single-cell origin theory proposed by Arnold (1979). In the dictyopterans species (Fenoglio et al., 1993), however, intermediate features of granulocytes and spherulocytes led to hypothesize a developmental relationship between both, as postulated by Gupta (1985).

According to our findings, the occurrence of cells with intermediate morphological characteristics and staining after Giemsa treatment indicate the transformation of granulocytes in oenocytoids. This fact is in accordance with the theory of Gupta (1985), which proposes granulocytes with potentiality to differentiate in adipohemocytes, spherulocytes and oenocytoids, but disagrees with the single-cell and multiple-cell origin theories proposed by Arnold (1979).

In relation to circulating hemocyte counts, our results showed a greater number of hemocytes in parasitized than in unparasitized larvae at the end of the 3rd instar but not at the beginning. These findings are in agreement with those obtained by Silva (2000), which detected encapsulation process against parasitoids only at the end of the 3rd instar A. obliqua larvae. According to DHC this greater number of hemocytes is on account of increase in the prohemocytes number.

The increase in the hemocytes number in the hemolymph of insects is a normal response to parasitism (Nappi, 1981; Eslin \& Prévost, 1998). Therefore, the difference in hemocytes population between unparasitized and parasitized A. obliqua larvae indicates that the host defense system was activated (Nappi, 1981; Brehélin, 1982). 
The present work contributes to characterization of the hemocytes of A. obliqua. However, further analysis are still required to bring additional details about the functions of each hemocyte type, in order to understand how the host is able to respond to endoparasitism in a cellular manner.

\section{REFERENCES}

ARNOLD, J. W., 1974, The hemocytes of insects. In: M. Rockstein, The physiology of insecta. New York, Academic Press, 5: 201-254.

ARNOLD, J. W. \& HINKS, C. F., 1976, Haemopoiesis in Lepidoptera. I. The multiplications of circulating haemocytes. Can. J. Zool., 54: 1003-1012.

ARNOLD, J. W., 1979, Controversis about hemocyte types in insects. In: A. P. Gupta, Insect hemocytes: development, forms, functions, and techniques. New York, Cambridge University Press, pp. 231-258.

BARRACO, M. A. \& CESTARI, A. N., 1984, Studies on the hemocytes of Trichosia pubescens (Diptera: Sciaridae) larvae. Rev. Brasil. Genet., II: 451-475.

BEAUlATON, J., 1979, Hemocytes and hemopoiesis in silkworms. Biochimie, 61: 157-164.

BREHÉLIN, M., 1982, Comparative study of structure and function of blood cells from two Drosophila species. Cell Tiss. Res., 221: 607-615.

BRESSAN, S., 1987, Aspectos do comportamento reprodutivo e ecológico de Anatrepha obliqua (Macquart, 1835) (Diptera, Tephritidae) na natureza. Tese de Doutorado, Faculdade de Medicina de Ribeirão Preto, Universidade de São Paulo, Ribeirão Preto, Brasil, 138p.

CANAL, N. A. D., ZUCCHI, R. A., SILVA, N. M. \& SILVEIRA NETO, S., 1996, Análise faunística dos parasitóides (Hymenoptera, Braconidae) de Anastrepha spp. (Diptera, Tephritidae) em Manaus e Iranduba, Estado do Amazonas. Acta Amaz., 25: 235-246.

CHIANG, A. S., GUPTA, A. P. \& HAN, S. S., 1988, Arthropod immune system: I. Comparative light and electron microscopy accounts of immunocytes and other hemocytes of Blattella germanica (Dictyoptera: Blattellidae). J. Morphol., 198: 257-267.

DEVAUCHELLE, G., 1971, Étude ultrastructure des hemocytes du coleoptere Melolontha melolontha (L.). J. Ultrastruct. Res., 34: 492-516.

ESLIN, P. \& PRÉVOST, G., 1998, Variation in Drosophila concentration of haemocytes associated with different ability to encapsulate Asobara tabida larval parasitoid. J. Insect Physiol., 42: 549-555.

FENOGLIO, C., BERNARDINI, P. \& GERVASO, M. V., 1993, Cytochemical characterization of the hemocytes of Leucophaea moderae (Dyctyoptera-Blaberoidea). $J$. Morphol., 218: 115-126.
GIANOTTI, E. \& CAETANO, F. H., 1985, A comparative study of the hemocytes of Atta laevigata adults (Formicidae-Myrmicinae). Rev. Brasil. Genet., 8: 37-45.

GIANOTTI, E. \& CAETANO, F. H., 1991, Caracterização morfológica dos hemócitos de Polistes lanio lanio (Hymenoptera-Vespidae) durante o desenvolvimento pósembrionário. Rev. Brasil. Biol., 51: 179-184.

GILLESPIE, J., KANOST, M. R. \& TRENCZEK, T., 1997, Biological mediators of insect immunity. Ann. Rev. Entomol., 42: 611-643.

GUPTA, A. P., 1979, Hemocyte types: their structure, synonimies, interrelationships, and taxonomic significance. In: A. P. Gupta, Insect hemocytes. Cambridge University Press.

GUPTA, A. P., 1985, Cellular elements in the hemolymph. In: G. A. Kerkut \& L. I. Gilbert, Comprehensive insect physiology biochemistry and pharmacology. Vol. 3, Pergamon Press, Oxford.

KAAYA, G. P., RATCLIFFE, N. A. \& ALEMU, P., 1986, Cellular and humoral defenses of Glossina: reactions against bacteria, trypanosomes and experimental implants. J. Med. Entomol., 23: 30-43.

MAlaVASI, A., MORGANTE, J. S. \& ZUCCHI, R. A., 1980, Biologia de "moscas-das-frutas" (Diptera: Tephritidae). I. Lista de hospedeiros e ocorrência. Rev. Brasil. Biol., 40: 9-16.

MALL, S. B. \& GUPTA, A. P., 1980, Free hemocytes in the adult red pumpkin beetle Aulacophora foveicollis. Indian J. Entomol., 41: 223-230.

NAPPI, A. J., 1981, Cellular immune response of Drosophila melanogaster against Asobara tabida. Parasitol., 83: 319-324.

NAPPI, A. J. \& CARTON, Y., 1986, Cellular immune response and their genetic aspects in Drosophila. In: M. Brehélin, Immunity in invertebrates. Vol. 13. SpringerVerlag, Berlin, Heidelberg, pp. 171-187.

OLSON, K. \& CARLSON, S. D., 1974, Surface fine structure of hemocytes of Periplaneta americana: a scanning electron microscope study. Ann. Entomol. Soc. Am., 67: 61-65.

PRICE, C. D. \& RATCLIFFE, N. A., 1974, A reappraisal of insect haemocyte classification by the examination of blood from fifteen insect orders. Z. Zellforsch. Mikrosk. Anat., 147: 313-324.

RATCLIFFE, N. A., 1993, Cellular defense responses of insects: unresolved problems. In: N. E. Beckage, S. N. Thompson \& B. A. Federici, Parasites and pathogens of insects. Vol. 1, Academic Press, New York.

RIZKI, R. M. \& RIZKI, T. M., 1980, The direction of evolution in the Drosophila melanogaster species subgroup based on functional analyses of the crystal cells. J. Exp. Zool., 212: 323-328.

RIZKI, T. M. \& RIZKI, R. M., 1992, Lamellocyte differentiation in Drosophila larvae parasitized by $L$. boulardi. Dev. Comp. Immunol., 16: 103-110. 
RUSSO, J., ALLO, M. R., NENON, J. P. \& BREHÉLIN, M., 1994, The hemocytes of the mealybugs Phenacoccus manihoti and Planococcus citri (Insecta: Homoptera) and their role in capsule formation. Can. J. Zool., 72: 252-258.

SILVA, J. E. B., 2000, Interação entre Anastrepha obliqua (Diptera-Tephritidae) e parasitóides durante o estágio larval. Dissertação de Mestrado, Faculdade de Filosofia, Ciências e Letras de Ribeirão Preto, Universidade de São Paulo, Ribeirão Preto, Brasil, 112p.

TELES DA SILVA, M., 1978, Aspectos morfológicos de algumas espécies de moscas-das-frutas do gênero Anastrepha (Diptera, Tephritidae). In: III Congresso Latino-Americano de Entomologia. Programas e resumos. Sociedade Entomológica do Brasil, Ilhéus, Bahia.
WHARTON, R. A., 1989, Classical biological control of fruit infesting tephritidae. In: A. S. Robinson \& G. Hooper, Fruit flies: their biology, natural enemies and control. Elsevier, New York, pp. 303-313.

WHITTEN, J. M., 1964. Haemocytes and the metamorphosing tissues in Sarcophaga bullata, Drosophila melanogaster, and other cyclorrhaphous Diptera. J. Insect Physiol., 10: 447-469. 